\title{
Looking for high-production and sustainable diets for lactating cows: A survey in Italy
}

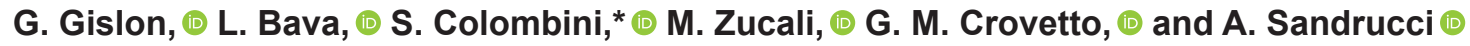 \\ Dipartimento di Scienze Agrarie e Ambientali-Produzione, Territorio, Agroenergia, Università degli Studi di Milano, via Celoria 220133 Milan, Italy
}

\begin{abstract}
The aim of the present study was to evaluate, through a survey conducted on commercial farms, the global warming potential (GWP) of different lactating cow total mixed rations (TMR) and to identify the best dietary strategies to increase feed efficiency (FE) and reduce enteric $\mathrm{CH}_{4}$ emission. A total of 171 dairy herds were selected: data about dry matter intake (DMI), lactating cow TMR composition, and milk production and composition were provided by farmers. Diet GWP ( $\mathrm{kg}$ of $\mathrm{CO}_{2}$ equivalents; $\mathrm{CO}_{2} \mathrm{eq}$ ) was calculated as sum of GWP ( $\mathrm{kg}$ of $\left.\mathrm{CO}_{2} \mathrm{eq}\right)$ of each included ingredient, considering inputs needed at field level, feed processing, and transport. For soybean solvent meal, land use change was included in the assessment. Enteric methane production $(\mathrm{g} / \mathrm{d})$ was estimated [using the equation $\left.\mathrm{CH}_{4}(\mathrm{~g} / \mathrm{d})=2.54+19.14 \times \mathrm{DMI}\right]$ to calculate $\mathrm{CH}_{4}$ emission for kilograms of fat- and protein-corrected milk (FPCM). The data set was analyzed by generalized linear model and logistic analysis using SAS 9.4 (SAS Institute Inc., Cary, NC). The frequency distribution showed wide variation among farms for GWP $(\mathrm{kg}$ of $\mathrm{CO}_{2}$ eq) of TMR: approximately $25 \%$ of the surveyed farms showed a diet GWP of $15 \mathrm{~kg}$ of $\mathrm{CO}_{2} \mathrm{eq}, 20 \%$ showed a GWP of $13 \mathrm{~kg}$ of $\mathrm{CO}_{2} \mathrm{eq}$, and $16.7 \%$ showed a GWP of $17 \mathrm{~kg}$ of $\mathrm{CO}_{2}$ eq. The variation among farms was due to the feedstuffs used. Among feedstuffs, soybean meal (SBM) had the highest correlation with the GWP of the TMR as shown by the following equation: TMR GWP $\left(\mathrm{kg}\right.$ of $\left.\mathrm{CO}_{2} \mathrm{eq}\right)=2.49 \times \mathrm{kg}$ of $\mathrm{SBM}+6.9$ $\left(\mathrm{R}^{2}=0.547\right)$. Moreover, diets with inclusion of SBM $>15 \%$ of dry matter (DM) did not result in higher milk production than diets with a lower inclusion of SBM $(\leq 15 \%)$. Average daily milk production of cows was 29.8 [standard deviation (SD) 4.83 ] $\mathrm{kg}$ with fat and protein contents of $3.86 \%$ (SD 0.22) and 3.40\% (SD 0.14), respectively. The average DMI $(\mathrm{kg} / \mathrm{d})$ of lactating cows
\end{abstract}

Received June 27, 2019.

Accepted December 23, 2019.

*Corresponding author: stefania.colombini@unimi.it was 22.3 (SD 2.23). Logistic analysis demonstrated that corn silage $\leq 30 \%$ of diet DM was associated with higher FE. Almost $50 \%$ of farms had an average value of $15.0 \mathrm{~g}$ of $\mathrm{CH}_{4} / \mathrm{kg}$ of FPCM and about $30 \%$ of farms had an average of $12.5 \mathrm{~g}$ of $\mathrm{CH}_{4} / \mathrm{kg}$ of FPCM. The results demonstrated that lower enteric $\mathrm{CH}_{4}$ production was related to inclusion (\% of diet DM) of $\leq 12 \%$ alfalfa hay and $>30 \%$ corn silage. Diets with $>34 \%$ neutral detergent fiber had higher $\mathrm{CH}_{4}$ production $(>14.0 \mathrm{~g} /$ $\mathrm{kg}$ of FPCM) than those with lower neutral detergent fiber content. In contrast, lower enteric $\mathrm{CH}_{4}$ production $(\leq 14.0 \mathrm{~g} / \mathrm{kg}$ of $\mathrm{FPCM})$ was related to diets characterized by net energy of lactation $\left(\mathrm{NE}_{\mathrm{L}}\right)>1.61 \mathrm{Mcal} / \mathrm{kg}$ and $>4 \%$ ether extract. The variability in TMR GWP shows significant potential for reducing the GWP of a diet through choice and inclusion levels of ingredients (mainly SBM) and the possibility of decreasing methane enteric emission associated with milk production on a commercial scale.

Key words: diet composition, feed efficiency, global warming potential, enteric methane emission

\section{INTRODUCTION}

Key indicators of climate change (e.g., increased global average temperatures, changes in patterns of precipitation, increased cloud cover, and more frequent floods) are widely accepted to be due to the radiative forcing effects of increased concentrations of greenhouse gases (GHG) in the atmosphere. Deforestation in the tropics and consequent land use change (LUC) for agricultural activity is also a factor contributing to the increased emission of GHG in the atmosphere (Hopkins and Del Prado, 2007). The increase in the concentration of GHG in the atmosphere is considered mainly related to anthropogenic activities, of which agriculture and livestock production play an important role.

Using a global life cycle assessment approach, the dairy production system in 2015 was estimated to have emitted 1,711.8 million tonnes of $\mathrm{CO}_{2}$ equivalents $\left(\mathbf{C O}_{2} \mathbf{e q}\right)$, which represents about $3.2 \%$ of the total anthropogenic emissions (FAO, 2019). The dairy sector contributes to GHG emissions through enteric fer- 
mentation, manure management, and crop cultivation for feed on and off the farm (Hassanat et al., 2017; FAO, 2019). Methane emissions are by far the largest contributor to the GHG emission profile of the dairy cattle sector, accounting for about $58.5 \%$ of the total (FAO, 2019). The level of enteric methane emission is mainly determined by feed intake, composition of the diet, forage preservation, and the rate of fermentation of different carbohydrate sources in the rumen (Boadi et al., 2004). Strategies to reduce enteric $\mathrm{CH}_{4}$ include supplementing diets with feed additives (e.g., plant extracts as condensed tannins, saponins, and essential oils) and dietary fats, offering diets rich in starch, improving forage quality, and changing the forage type used in the TMR (e.g., increased corn silage to replace grass; Little et al., 2017). Forages are one of the main components of dairy cow diets: they represent from 30 to $80 \%$ of dietary DM (Gallo et al., 2013). In the Po Plain of northern Italy, the main forages fed to dairy cattle are corn silage, alfalfa (silage or hay), and cool-season crops (silage or hay). A study conducted by Zucali et al. (2018) in 134 farms in the same area as the present study showed that corn for whole-plant silage was the crop most frequently grown as a single ( $83 \%$ of the farms) or double $(54 \%)$ crop, followed by permanent grass hay $(80 \%)$ and alfalfa (hay or silage, $58 \%$ ). Because this forage is so widespread in the area and used in high amounts in lactating cow diets, it would be useful to evaluate the optimum level of corn silage to be included in the diet to optimize milk production and decrease methane emission per kilogram of fat- and protein-corrected milk (FPCM). Overall, the potential effect of all main ingredients included in a TMR should be considered; for example, as reported by Evans (2018), the choice of forage such as maize silage is an easy strategy to use when $\mathrm{CH}_{4}$ mitigation is solely considered but should be questioned when associated GHG production is taken into account. Feed production, both on farm (mainly forages) and off farm (mainly concentrates), and transportation are responsible for a significant amount of GHG emission as well; for example, Bava et al. (2014) showed that emissions related to production of concentrated feed is about the $20 \%$ of total GHG impact for milk production. After emissions from enteric fermentation (accounting for $46 \%$ ), therefore, feed emissions represent the second largest category, contributing about $36 \%$ of total emissions in the dairy supply chain (Gerber et al., 2013).

To the best of our knowledge, no studies or feeding models have investigated or implemented an evaluation of global warming potential (GWP) associated with the use of different ingredients in diets for lactating cows. In fact, GHG emission from animal feeding is not limited to enteric and manure methane emission but also to the $\mathrm{CO}_{2} \mathrm{eq}$ associated with production of different feeds. Therefore, the aims of the present work were to (1) quantify the GWP of different lactating cow TMR commonly used in intensive farms and to identify the optimal feed ingredient composition to decrease GWP; and (2) determine the best dietary strategies to increase feed efficiency $(\mathbf{F E})$ and reduce enteric $\mathrm{CH}_{4}$ emission on a commercial farm scale.

\section{MATERIALS AND METHODS}

\section{Farm Data Collection}

A representative sample of 171 Italian Holstein dairy herds was selected, in the Lombardy region (northern Italy). Farms were chosen from milk producers who participated in the milk national quality control program, consisting of individual milk sample collection (every $40 \mathrm{~d}$ ) and analysis by the extension service laboratory. Milk was analyzed for fat and protein (MilkoScan FT6000; Foss Analytical A/S, Hillerød, Denmark) in the dairy service extension laboratory. The average number of cows was 156 [standard deviation (SD) 116], whereas the utilized agricultural area was, on average, 84.4 ha (SD 82.3); all farms used a TMR as diet supply. Each farm was visited once for collecting data (provided by farmers) on estimated DMI, lactating cow TMR ingredient composition and chemical analysis, and milk production and composition (fat and protein content). For each farm, the amounts of homegrown forages and concentrates (commercial mixed feed and raw materials both homegrown and purchased, depending on the farm) used in the diets were recorded. For some farms that used commercial mixed feeds, the exact amount of each ingredient used in the mix was not declared by producers; hence, for these farms, the mix formula was estimated through the Cornell Net Carbohydrate and Protein System (CNCPS version 6.1; Cornell University, Ithaca, NY; Tylutki et al., 2008), based on the declared chemical composition of the mix and on the raw materials included in the formula, which were listed by the producers in a rank based on a predominance according to weight.

Chemical composition of the TMR (ash, CP, ether extract, NDF, and NFC), obtained through chemical or near infrared (NIR) analysis, was provided by farmers.

Milk production was transformed to FPCM according to the International Dairy Federation (IDF, 2015) equation:

$$
\begin{aligned}
& \text { FPCM }(\mathrm{kg})=\text { milk production }(\mathrm{kg}) \times[0.1226 \\
& \times \text { fat }(\%) \times 0.0776 \times \text { protein }(\%)+0.2534] .
\end{aligned}
$$




\section{Feed and Diet GWP Calculation}

The GWP ( $\mathrm{kg}$ of $\mathrm{CO}_{2} \mathrm{eq}$ ) of individual daily TMR was calculated as the sum of GWP of each feed ingredient. The GWP of forages (corn silage, meadow hay, and alfalfa and Italian ryegrass hay and silage) was derived from a study performed in the same geographical area by Zucali et al. (2018).

The GWP of concentrates and raw materials was obtained from the Ecoinvent (2013), Eco-Alim (2015), and AgriFootprint (2014) databases. These databases provide documented process data about environmental impact of thousands of products.

For each ingredient in diets, GWP $\left(\mathrm{kg}\right.$ of $\mathrm{CO}_{2} \mathrm{eq} / \mathrm{kg}$ of DM) was calculated considering inputs needed at the field level (e.g., fossil fuel, seeds, fertilizers, pesticides, agricultural machines), feed processing (e.g., drying, ensiling) and national and transnational transport. For solvent soybean meal (SBM), direct LUC was included in the assessment. Different LUC methods result in significantly different outputs; in this study, we used the value reported by the AgriFootprint database (Soybean, at farm/BR Economic, AgriFootprint, 2014), considering $3.5 \mathrm{~kg}$ of $\mathrm{CO}_{2} \mathrm{eq} / \mathrm{kg}$ of SBM for SBM from South America. For all purchased SBM, we considered an amount of $20 \%$ from Italy and $80 \%$ from South America (ASSALZOO, 2018). For all farms, diet GWP was calculated as sum of GWP of each ingredient included in the TMR.

\section{Enteric Methane Production}

The published equations summarized by Appuhamy et al. (2016), to estimate $\mathrm{CH}_{4}$ produced by lactating cows, were tested on a data set of in vivo trials, conducted on lactating cows fed diets based on different forages produced in the same area of the study (Colombini et al., 2015; Pirondini et al., 2015). The equation of Hristov et al. (2013) resulted in the highest coefficient of determination $\left(\mathrm{R}^{2}\right)$ value $(0.880$; root mean square error: 15.3) between predicted and observed values; hence, it was used to estimate enteric methane production as follows:

$$
\mathrm{CH}_{4}(\mathrm{~g} / \mathrm{d})=2.54+19.14 \times \text { DMI }
$$

\section{Statistical Analysis}

The complete data set was analyzed using SAS 9.4 (2012; SAS Institute Inc., Cary, NC) using descriptive statistic procedures including frequency (FREQ), distribution (CHART), simple regression (REG), and means (MEAN).
The relationship between TMR characteristics (ingredients and chemical composition) and estimated enteric methane emission was evaluated through 2 multiple correspondence analyses (Proc CORRESP) to report a 2-dimensional graphical representation of the rows and columns of a contingency table. Data were analyzed by Proc GLM to test the influence of SBM $(\leq 10 \%$, $10-15 \%$, and $>15 \%)$, corn silage $(\leq 30 \%$ and $>30 \%)$ and corn grain meal $(\leq 20 \%$ and $>20 \%)$ inclusions and of NDF ( $\leq 34.0$ and $>34.0 \%$ on DM) and energy $(\leq 1.61$ and $>1.61 \mathrm{Mcal} / \mathrm{kg}$ of DM) contents on ration chemical composition and milk production.

Multivariate logistic analyses were performed by LOGISTIC procedure to identify the main management factors associated with high level of $\mathrm{FE}(>1.30 \mathrm{~kg}$ of FPCM/kg of DMI). The threshold was chosen based on the mean of the variable in the whole data set. The logistic regression analyses examined all the possible interactions among variables. Variables or combinations of variables (interaction terms) were excluded through a stepwise backward multiple regression method based on a $20 \%$ significance level. The results of the analyses built a final model including variables (risk factors) that were significantly associated with $\mathrm{FE}(>1.3 \mathrm{~kg}$ of FPCM $/ \mathrm{kg}$ of DMI). The final models were described in terms of odds ratios and $95 \%$ confidence intervals.

\section{RESULTS AND DISCUSSION}

\section{Diet Composition}

All the diets adopted by farmers were formulated to satisfy nutrient requirements for milk production according to Cornell Net Carbohydrate and Protein System (version 6.5), as described by Van Amburgh et al. (2015). Average chemical composition of TMR is given in Table 1.

Considering the main forages used in the TMR, corn silage was used in $92 \%$ of surveyed farms (Figure 1). The main reasons for such a high use of corn silage in the Po Plain are its high agronomic yield and high-energy value mainly because of its starch content. Because of

Table 1. Average nutrient composition (DM basis; \% unless otherwise noted) of the lactating cow rations fed in the surveyed dairy farms

\begin{tabular}{|c|c|c|c|c|}
\hline Nutrient & Mean & $\mathrm{SD}$ & Minimum & Maximum \\
\hline$\overline{\mathrm{CP}}$ & 15.7 & 1.09 & 10.0 & 18.4 \\
\hline NDF & 33.9 & 3.44 & 26.3 & 45.6 \\
\hline $\mathrm{ADF}$ & 20.7 & 2.82 & 11.4 & 30.0 \\
\hline $\mathrm{NFC}$ & 39.8 & 3.35 & 29.8 & 49.9 \\
\hline Starch & 27.2 & 2.99 & 14.2 & 35.7 \\
\hline Ether extract & 3.89 & 1.11 & 0.71 & 8.13 \\
\hline Ash & 7.28 & 1.58 & 4.37 & 13.1 \\
\hline $\mathrm{NE}_{\mathrm{L}}(\mathrm{Mcal} / \mathrm{kg})$ & 1.61 & 0.14 & 1.19 & 1.96 \\
\hline
\end{tabular}




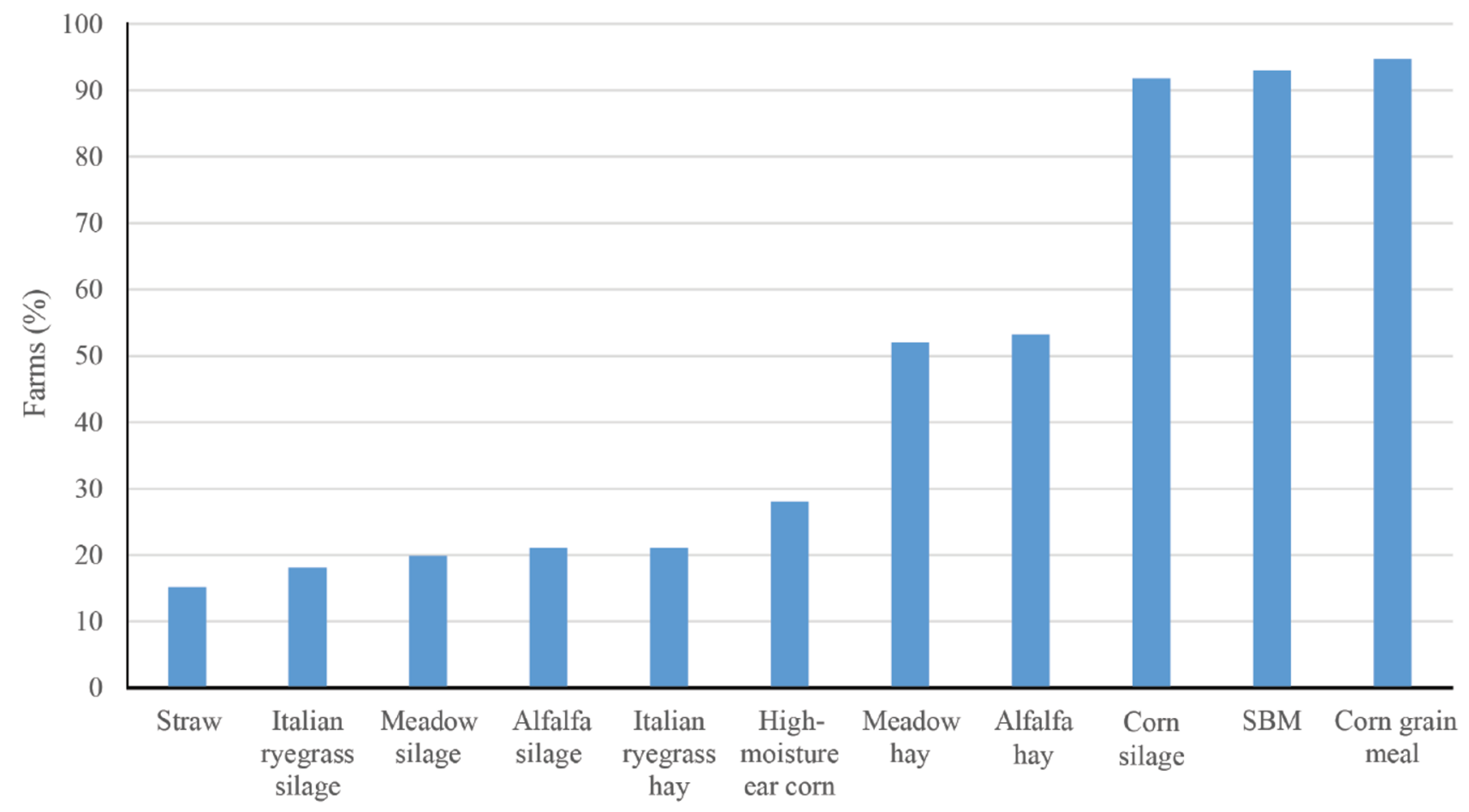

Figure 1. Utilization of main ingredients (\% of farms that use the feed) for lactating cow TMR formulation ( $\mathrm{n}=171$ herds). SBM $=$ soybean meal.

its high starch content, corn silage is considered a good source of ruminally fermentable carbohydrates (Dhiman and Satter, 1997; Brito and Broderick, 2006).

As reported in Figure 2, corn silage was used in significant amounts representing, on average, 29.6\% (SD 11.1\%) of the diet (on a DM basis). This value is similar to that $(29.0 \%)$ reported by Pirondini et al. (2012) for commercial dairy farms of the Po Plain and much higher than the value (15\%) reported by Arriaga et al. (2009) in the Basque Country. This confirms that environmental conditions in northern Italy are favorable to the production of corn silage, as also reported by Zucali et al. (2018).

The other forages used in TMR were Italian ryegrass and meadow and alfalfa hays; they were used in 21 , 52 , and $53 \%$ of the farms, respectively (Figure 1). The average inclusion (\% of DM) was 9.69 (SD 8.56) for Italian ryegrass hay, 11.4 (SD 8.00) for meadow hay, and 13.0 (SD 5.79) for alfalfa hay. In contrast, these same forages preserved as silage were used on fewer farms: Italian ryegrass silage was present in $18 \%$ of farms, meadow silage in 19\%, and alfalfa silage in $21 \%$ (Figure 1).

Considering concentrates, SBM was used in $93 \%$ of the farms (Figure 1). However, the amounts used in the ration (\% of DM) were different; in $28 \%$ of farms, SBM was $\leq 10 \%$; in $46 \%$ of farms SBM ranged from 10 to
$15 \%$; and in $26 \%$ of farms, SBM was $>15 \%$. These differences resulted in different $(P=0.003) \mathrm{CP}$ contents of the diets: $15.3,15.9$, and $16.0 \%$ of DM, respectively. However, variation in inclusion level of SBM did not significantly affect $(P=0.470)$ milk production, which was $29.0,29.9$, and $29.2 \mathrm{~kg}$ of FPCM for the 3 groups of farms, respectively. Therefore, it seems that for feeding systems of northern Italy, high inclusion of SBM $(>15 \%$ on diet DM) in the diet is not necessarily linked to an improvement in milk production. Similarly, Olmos Colmenero and Broderick (2006) obtained the best results for FCM yield $(36.7 \mathrm{~kg} / \mathrm{d})$ with inclusion of $9.2 \% \mathrm{SBM}$ (DM basis), in addition to $25 \%$ alfalfa silage.

Corn grain meal was used in more than $95 \%$ of the surveyed farms, compared with high-moisture ear corn that was used in only $28 \%$ of the farms, with dietary inclusion (\% of DM) of 13.7 (SD 8.98) and 5.23 (SD 8.81 ), respectively (Figure 1). The availability of carbohydrates for ruminal microbes and the host animal is affected by grain source and processing (Ekinci and Broderick, 1997). Compared with corn grain meal, high-moisture ear corn, due to the fermentation process, has a greater starch rumen degradability and, thus, greater digestibility (McCaffree and Merrill, 1968; Clark and Harshbarger, 1972). Cows fed high-moisture ear corn show higher milk yield than those fed corn grain meal (Clark et al., 1973; De Brabander et al., 

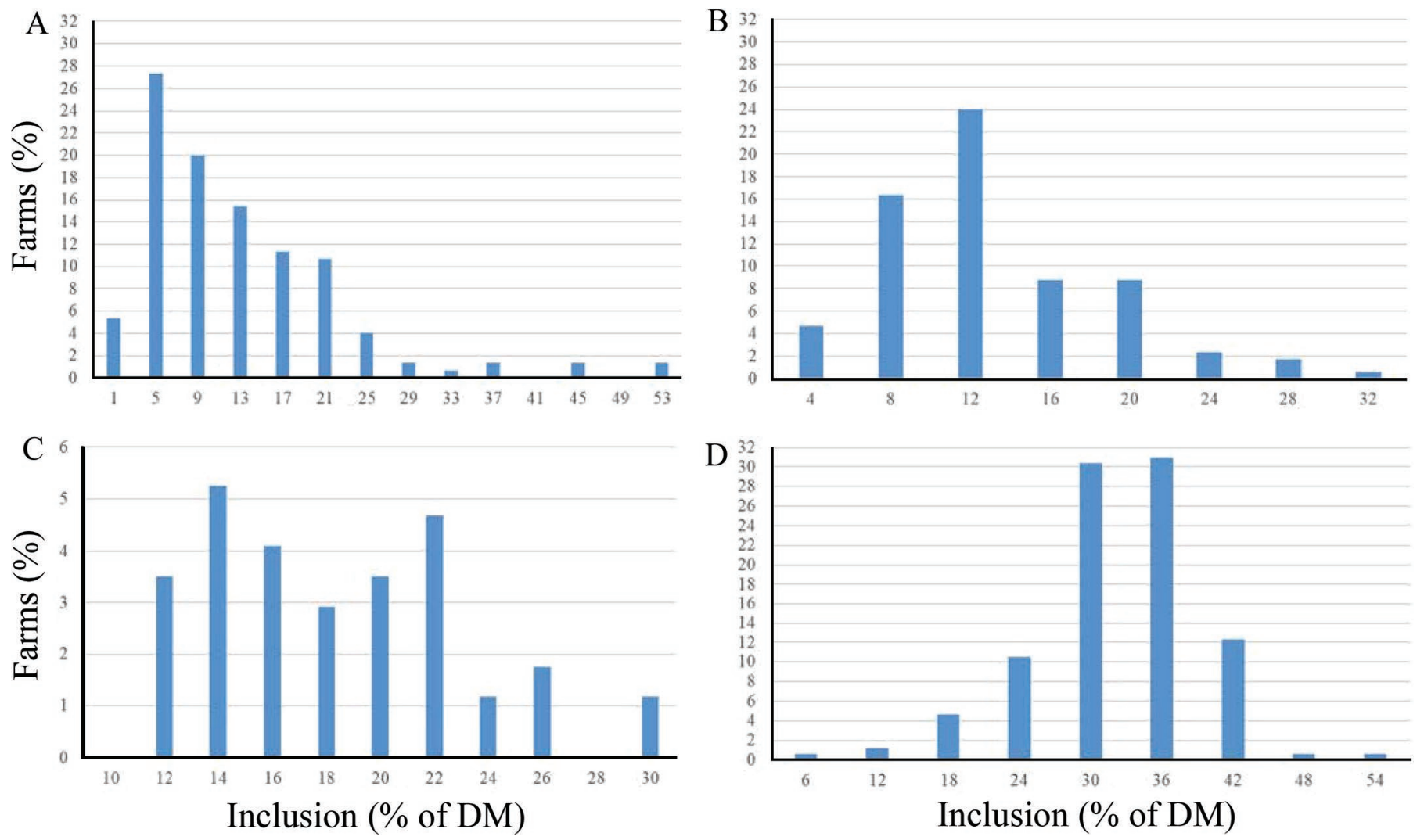

Figure 2. Level of inclusion (\% of DM) in the lactating cow TMR of the main ingredients in the studied farms ( $\mathrm{n}=171$ herds): (A) Italian ryegrass and meadow hay; (B) alfalfa hay; (C) high-moisture ear corn; (D) corn silage

1992). Therefore, the use of high-moisture ear corn may be increased in dairy farms because of promising results in terms of milk production and earlier harvest than for the production of dry corn meal.

\section{Diet Composition and GWP}

Diet GWP corresponded to an average of 0.61 (SD $0.15) \mathrm{kg}$ of $\mathrm{CO}_{2} \mathrm{eq} / \mathrm{kg}$ of $\mathrm{DM}$, with an average value of 13.7 (SD 3.71) kg of $\mathrm{CO}_{2}$ eq for the total daily administered TMR (Figures 3 and 4). However, wide variation was found among farms for these values: more than $26.3 \%$ of the surveyed farms showed an individual daily diet GWP of $15 \mathrm{~kg}$ of $\mathrm{CO}_{2} \mathrm{eq}, 20 \%$ of the farms showed a GWP value of $13 \mathrm{~kg}$ of $\mathrm{CO}_{2} \mathrm{eq}$, and more than $17.7 \%$ of farms had a GWP of $17 \mathrm{~kg}$ of $\mathrm{CO}_{2}$ eq. These reported values are those with the highest frequency; however, approximately $28 \%$ of farms were characterized by low GWP $\left(<11 \mathrm{~kg}\right.$ of $\left.\mathrm{CO}_{2} \mathrm{eq}\right)$ and a smaller percentage of farms $\left(8.74 \%\right.$ ) by GWP $>17 \mathrm{~kg}$ of $\mathrm{CO}_{2}$ eq.

The variation among farms for TMR GWP is due to the feed ingredients used and to feed production and transportation, which are presumed responsible for the high amount of GHG emissions (Ogino et al., 2007).
According to FAO (2019), emissions $\left(\mathrm{CO}_{2}\right.$ and $\left.\mathrm{N}_{2} \mathrm{O}\right)$ from feed production, processing, and transportation account for $29.4 \%$ of total emission from the dairy sector.

The variability of GWP among diets is directly related to their feed composition and to the GWP of each feed. For example, using concentrates to lower $\mathrm{CH}_{4}$

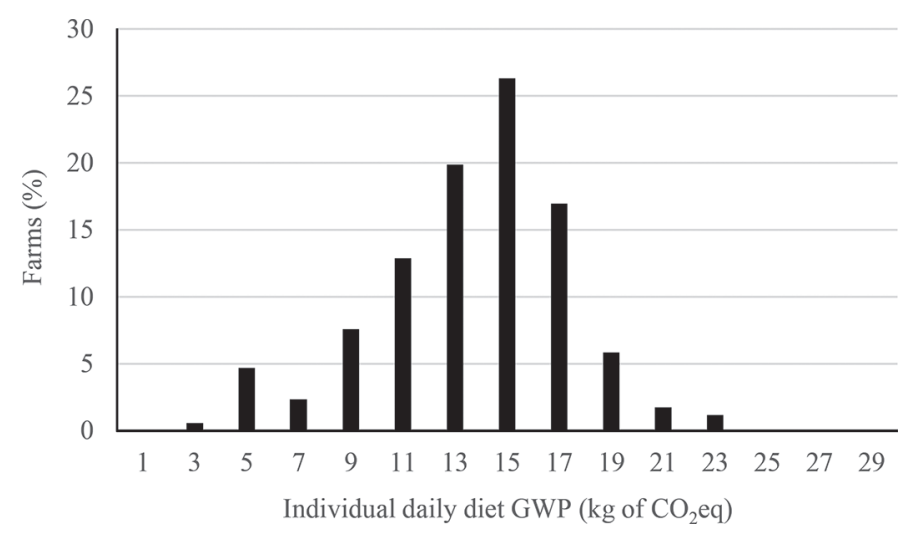

Figure 3. Frequency distribution (\% of farms) of daily diet global warming potential (GWP; $\mathrm{kg}$ of $\mathrm{CO}_{2}$ equivalents) in the studied farms ( $\mathrm{n}=171$ herds). 
emissions in ruminants could have limited advantages because increased dietary concentrates might increase total net emissions. Using a large amount of concentrates requires huge inputs for growing, processing, and transportation, leading to increased use of pesticides, fertilizers, and ancillary sources of emissions associated with production and transportation infrastructure (Beauchemin et al., 2008) and change of land use. Ogino et al. (2007) reported that production and transportation of concentrates for animal feeding produced 2.1 times as much $\mathrm{CO}_{2}$ as that of roughage per unit of total digestible nutrient.

Considering forage ingredients, as previously reported, corn silage was the main forage source of the studied TMR. However, compared with alfalfa silage, corn silage implies greater $\mathrm{CO}_{2}$ emission due to increased energy demand for its production that can be attributed to cropping practices, including use of fertilizers, lime, and herbicide (Little et al., 2017). Planting perennial forages such as alfalfa, moreover, might reduce agricultural GHG emissions by sequestering $\mathrm{CO}_{2}$ in agricultural soils (Jarecki and Lal, 2003). Although changes in soil carbon can affect the carbon footprint of agricultural systems, they are rarely included in GHG analysis of dairy products because of the complexity and lack of consensus about the methodology (Little et al., 2017). Even in this study, carbon soil sequestration was not taken into account in evaluating the environmental impact of different feed sources; if we were to consider this aspect, the results obtained may change.

As previously reported, soybean meal was used in $92 \%$ of surveyed farms to satisfy the protein requirements of cows. Use of protein sources like SBM that generally comes from outside the farm (mostly South America) implies an addition in $\mathrm{CO}_{2}$ emission related to transport and LUC. In this study, the GWP value for SBM was $3.09 \mathrm{~kg}$ of $\mathrm{CO}_{2} \mathrm{eq} / \mathrm{kg}$ of DM (AgriFootprint, 2014 modified; http://www.agri-footprint.com) and included the environmental impact of $80 \%$ of SBM being imported from South America and 20\% of SBM produced locally, because Italy is not self-sufficient for this production. As expected (Figure 5), there was a linear correspondence between increasing daily diet GWP ( $\mathrm{kg}$ of $\mathrm{CO}_{2} \mathrm{eq}$ ) and increasing the amount of SBM in the ration. Although pasture expansion remains, by far, the primary direct cause of Amazonian deforestation, the increase in mechanized crop production such as for soybeans must also be viewed as a driver of deforestation, even if new fields only replace existing pastures or savannah lands (Arima et al., 2011). In some Brazilian states such as Mato Grosso, the increase in soybean crop in regions previously used for pasture may have displaced pastures further north into forested areas, causing indirect deforestation. Therefore, soy-

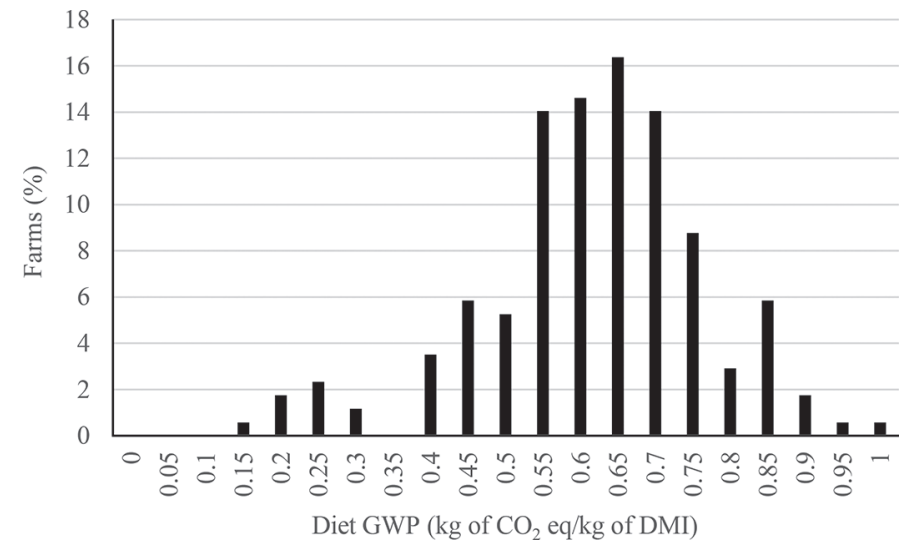

Figure 4. Frequency distribution (\% of farms) of diet global warming potential (GWP) for kilograms of DM in TMR ( $\mathrm{kg}$ of $\mathrm{CO}_{2}$ equivalents $/ \mathrm{kg}$ of $\mathrm{DM}$ ) in the studied farms ( $\mathrm{n}=171$ herds).

bean cultivation may still be one of the major causes of deforestation in the Legal Amazon (Barona et al., 2010; Lapola et al., 2010; Arima et al., 2011).

\section{Diet Composition and Feed Efficiency}

Knowledge of feed efficiency at the herd level is an important aspect that should be evaluated to increase farm profitability. In this regard, the choice of ingredients used to formulate TMR can strongly affect FE values. For example, as reported by Phuong et al. (2013), fiber, concentrate proportion, and digestible energy are the common nutritional factors affecting FE. For this reason, we studied the relationship between diet composition and FE through logistic analysis at the commercial farm scale. Average milk production of the

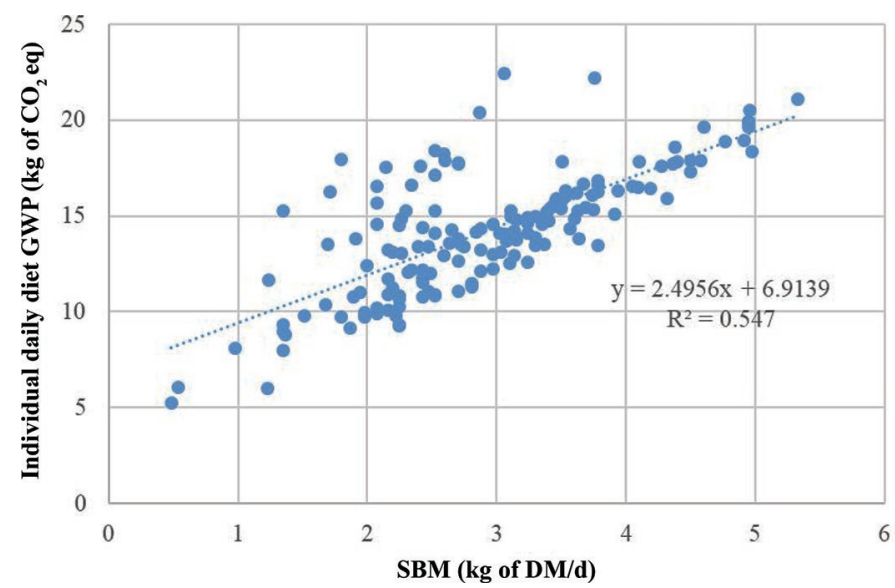

Figure 5. Relationship between dietary soybean meal amount (SBM; $\mathrm{kg} / \mathrm{d}$ ) and individual daily global warming potential (GWP; $\mathrm{kg}$ of $\mathrm{CO}_{2}$ equivalents) of the TMR in the studied farms ( $\mathrm{n}=171$ herds). 
Table 2. Logistic analysis of feed sources related to high feed efficiency level ( $>1.30 \mathrm{~kg}^{\circ} \mathrm{FPCM}^{1} / \mathrm{kg}$ of DMI)

\begin{tabular}{lccc}
\hline Effect & $\begin{array}{c}\text { Odds ratio } \\
\text { estimate }\end{array}$ & $95 \%$ CI & $P$-value \\
\hline Corn silage inclusion: $\leq 30 \%$ vs. $>30 \%$ of DM & 2.35 & $1.14-4.85$ & 0.021 \\
Corn grain meal inclusion: $\leq 20 \%$ vs. $>20 \%$ of DM & 2.10 & $1.11-3.97$ & 0.022 \\
Forages excluding corn silage: $\leq 20 \%$ vs. $>20 \%$ of DM & 2.03 & $1.00-4.13$ & 0.051 \\
\hline
\end{tabular}

${ }^{1}$ Fat- and protein-corrected milk.

surveyed farms was 29.8 (SD 4.83) with fat and protein contents (\%) of 3.86 (SD 0.22) and 3.40 (SD 0.14), respectively.

In this study, FE was affected by dietary amount (\% of TMR DM) of corn silage, other forage sources, and corn grain meal (Table 2). In particular, corn silage at $\leq 30 \%$ of DMI associated with the inclusion in the diet of other forage sources (e.g., alfalfa and grass hay) resulted in greater FE (Table 2). This result is in accordance with other studies, which demonstrated that a mix of different forage sources leads to an optimum balance in terms of energy and protein supply for milk production compared with either corn silage or another forage as the sole component of the forage (Dhiman and Satter, 1997; O'Mara et al., 1998; Brito and Broderick, 2006).

As described previously, corn silage is the main ingredient of lactating cow TMR in the Po Plain; however, the results of the present study confirm that a threshold level (approximately $\leq 30 \%$ ) exists that should be taken in account when formulating lactating cow diets. Farms with $<30 \%$ of corn silage included in the diet (\% of DM) showed an average FPCM production of $30.2 \mathrm{~kg} / \mathrm{d}$, whereas those with $>30 \%$ inclusion had an average FPCM production of $29.0 \mathrm{~kg} / \mathrm{d}(P=0.099$, for the difference in milk production according to corn silage inclusion).

The results shown in Table 2 indicate that an FE $>1.30$ is linked to inclusion in the diet of corn silage $\leq 30 \%$, corn grain meal $\leq 20 \%$, and forages excluding corn silage $\leq 20 \%$ (odds ratios $>1$ ). Hence, an excessive increase in corn grain meal in the diet is not related to any productive advantage for the animals. In the surveyed farms, therefore, FPCM production averaged 30.1 (SD 4.82) kg/d for the group with $\leq 20 \%$ (\% DM) corn grain meal, and 28.8 (SD 4.39) kg/d for those farms with $>20 \%$ of corn grain meal in the $\operatorname{diet}(P=0.073)$. According to Powell et al. (2016), feeding more corn grain meal does not significantly affect milk production (kg of FPCM/cow per day). Similarly, a review based on a meta-analytic approach to evaluate the effect of dietary starch on lactation performance by dairy cows (Ferraretto et al., 2013) showed that milk fat content decreased as dietary starch content increased and that milk fat depression in high-starch diets is likely related to greater starch and lower NDF intakes (Jenkins and McGuire, 2006).

\section{Diet Composition and Enteric Methane Emission}

The study was conducted on 171 commercial farms; hence, it was not possible to determine $\mathrm{CH}_{4}$ emission by direct measurement. The level of enteric methane emission is mainly determined by feed intake and by the composition of the diet (Boadi et al., 2004; Beauchemin et al., 2008; Martin et al., 2010); thus, in the present study, methane emission was estimated according to DMI using the equation of Hristov et al. (2013). The average value of DMI of lactating cows measured by farmers in the study was 22.3 (SD 2.23$) \mathrm{kg} / \mathrm{d}$. The results are reported as grams of methane/kilogram of milk production and composition (FPCM). Differently from methane, FPCM was measured directly by farmers; thus, the obtained results can provide useful information for the area of the study to rank farms and dietary strategies to evaluate $\mathrm{CH}_{4}$ emission per kilogram of FPCM.

As shown in Figure 6, most of the considered farms (almost $50 \%$ of those investigated) had an average value of $15.0 \mathrm{~g}$ of $\mathrm{CH}_{4} / \mathrm{kg}$ of $\mathrm{FPCM}$, followed by about $30 \%$ of farms with enteric methane production of 12.5 $\mathrm{g}$ of $\mathrm{CH}_{4} / \mathrm{kg}$ of FPCM. These values are in line with results obtained in several trials conducted using respiration chambers (Benchaar et al., 2014; Hassanat et al., $2013,2017)$. The wide variability among commercial farms for emissions shows that for a significant number of farms, emissions can be decreased by applying appropriate dietary strategies. For example, as shown in Figure 7, low enteric $\mathrm{CH}_{4}\left(\leq 14 \mathrm{~g}\right.$ of $\mathrm{CH}_{4} / \mathrm{kg}$ of $\mathrm{FPCM}$ ) production was related to the inclusion of $\leq 12 \%$ of alfalfa hay, $>30 \%$ of corn silage, and $\leq 20 \%$ of other forage sources excluding corn silage (i.e., Italian ryegrass and permanent meadow). Hassanat et al. (2013) demonstrated that feeding dairy cows corn silage as total replacement of alfalfa silage involves less $\mathrm{CH}_{4}$ emissions (in terms of $\mathrm{g} / \mathrm{kg}$ of DMI). Similarly, Aguerre et al. (2011) reported a higher $\mathrm{CH}_{4}$ emission per kilogram of both milk and ECM with increased forage proportion in the diet, in agreement with our results. Overall, the inclusion of corn silage in the diet (about 30\% dietary 


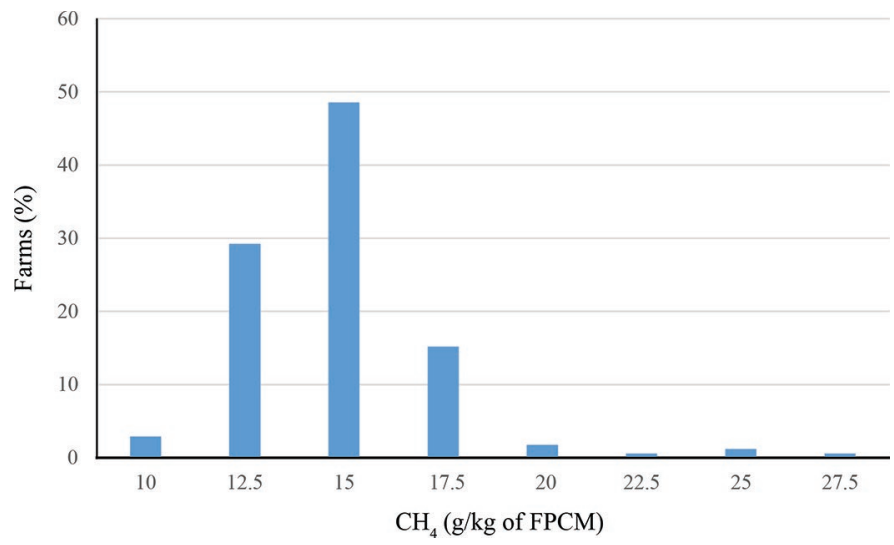

Figure 6. Frequency distribution (\% of farms) of estimated enteric methane production per unit of fat- and protein-corrected milk (FPCM) in the studied farms $(\mathrm{n}=171$ herds $)$.

DM) seems to be positively related to lower methane emission; however, as shown previously, the amount of corn silage used in the rations should not reduce the FE. This agrees with the results of van Gastelen et al. (2015), who showed lower methane emission by cows fed diets with corn silage instead of grass silage, although the calculated FE was lower for cows fed diets based on corn silage as sole forage source. The increase in dietary corn silage proportion is generally associated with some changes in the rumen, such as lower $\mathrm{pH}$ and acetate:propionate ratio, and reduced fiber digestibility (Hassanat et al., 2013), which can negatively affect cow performance.

Diets characterized by a high content of NDF, conversely, involve higher methane production at the enteric level. Roughage-based diets favor acetate production and increase $\mathrm{CH}_{4}$ per unit of fermentable $\mathrm{OM}$ (Johnson and Johnson, 1995). As shown in Figure 8, diets with $>34 \%$ NDF (\% of DM) resulted in enteric methane production $>14 \mathrm{~g} / \mathrm{kg}$ of FPCM. In the surveyed farms, cows fed diets with a lower NDF concentration $(\leq 34.0 \%)$ produced approximately $15.0 \%$ more FPCM $(31.6 \mathrm{~kg} / \mathrm{d})$ than cows fed diets with higher $\mathrm{NDF}(>34.0 \%$ ), which produced $27.2 \mathrm{~kg}$ of $\mathrm{FPCM} / \mathrm{d}$; this difference was significant $(P<0.001)$. In contrast, DMI was on average about $5 \%$ higher for cows fed diets with NDF $\leq 34.0 \%$ than for cow fed diets with NDF $>34.0 \%$ ( 22.8 vs. $21.7 \mathrm{~kg} / \mathrm{d}$ for low- and high-NDF di-

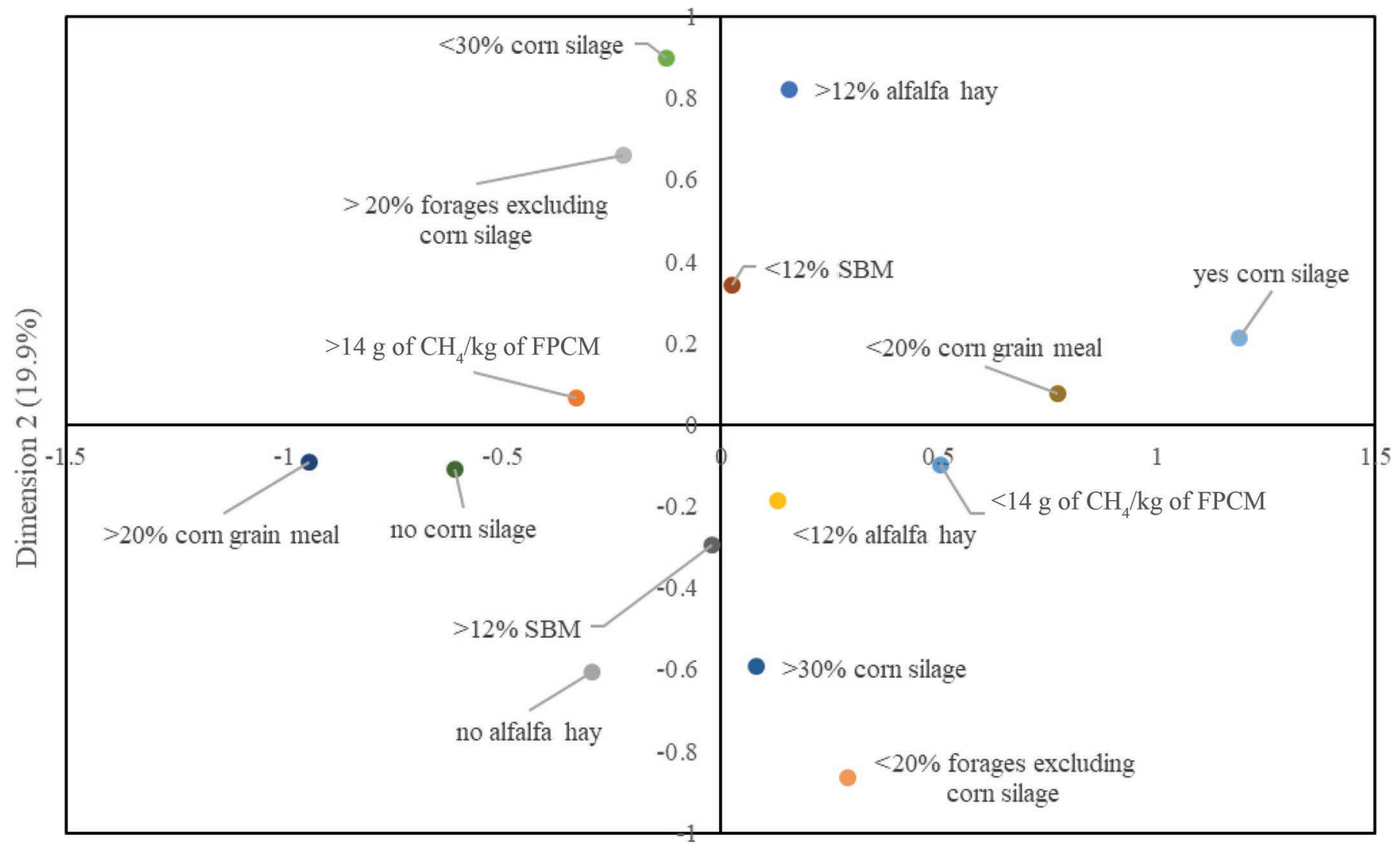

Dimension $1(21.7 \%)$

Figure 7. Correspondence analysis for methane production per kilogram of fat- and protein-corrected milk (FPCM) and feed inclusions (on $\mathrm{DM}$ basis) in the diet. $\mathrm{SBM}=$ soybean meal. 
ets; $P=0.002$ ); hence, cows fed diets with a high NDF content were less efficient overall, resulting in higher production of $\mathrm{CH}_{4} / \mathrm{kg}$ of $\mathrm{FPCM}$.

Similarly, as shown in Figure 8, diets characterized by more than $1.61 \mathrm{Mcal}$ of $\mathrm{NE}_{\mathrm{L}} / \mathrm{kg}$ tended to have $\leq 14$ $\mathrm{g}$ of $\mathrm{CH}_{4} / \mathrm{kg}$ of FPCM. Diets high in energy were formulated with a slightly higher concentrate inclusion (48.9 vs $46.4 \%$ on a DM basis, respectively, for high- and lowenergy diets; $P=0.03$ ) and consequently higher FPCM production (30.9 vs $28.2 \mathrm{~kg} / \mathrm{d} ; P<0.001$ ). Replacing structural carbohydrates from forages in the diet with the nonstructural carbohydrates contained in most energy-rich concentrates is associated with increases in feed intake, higher rates of ruminal fermentation, accelerated feed turnover, and a shift of VFA production from acetate toward propionate, which results in lower $\mathrm{CH}_{4}$ production (Johnson et al., 1996; Hegarty and Gerdes, 1999; Martin et al., 2010).
Similarly, lower enteric methane production was related to diets containing $>4.0 \%$ (DM basis) ether extract (Figure 8), which increases the dietary energy content. Moreover, dietary fat seems to act as a reducer of ruminal methanogenesis without affecting other ruminal parameters (Martin et al., 2010). In this regard, Giger-Reverdin et al. (2003) demonstrated that an increase of $1 \%$ dietary ether extract decreased methane production by $0.68 \mathrm{~L} / \mathrm{kg}$ of DM of feed. Similarly, considering methane/FPCM, Knapp et al. (2014) showed (by meta-analysis) that increasing ether extract content in the ration reduced $\mathrm{CH}_{4} / \mathrm{ECM}$, and this appeared to be achieved by dilution of fermentable carbohydrates in the DM and potentially reduced DMI (Knapp et al., 2014). The threshold value of ether extract of $4 \%$ on a DM basis was chosen to divide farms into 2 numerically equivalent groups. The data obtained indicate that increasing the ether extract content of the diet above

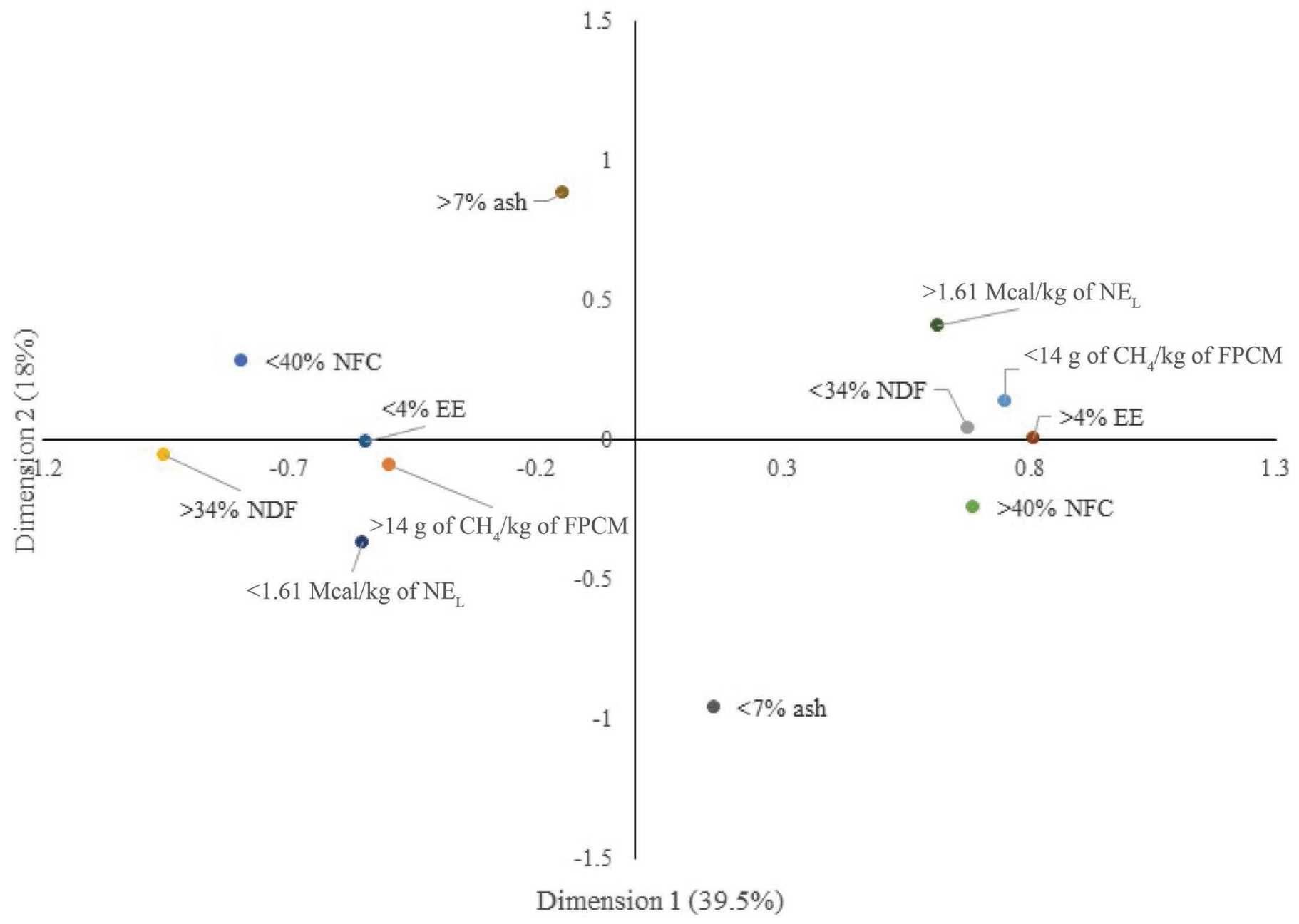

Figure 8. Correspondence analysis for methane production per kilogram of fat- and protein-corrected milk (FPCM) and chemical composition and energy content (on DM basis) of the diet. $\mathrm{EE}=$ ether extract. 
$4 \%$ is a simple but effective strategy for about half of the farms to reduce methane emission per kilogram of FPCM.

\section{CONCLUSIONS}

The results of this survey revealed that corn silage, corn grain meal, and soybean meal are the most popular ingredients included in TMR for lactating cows in northern Italy due to the high yield of corn and the high availability of the protein in soybean meal. However, the use of these feeds raises some concerns. Excessive inclusion in the diet of corn silage $(>30 \%)$ or corn grain meal $(>20 \%)$ is not related to higher milk yield and has a negative effect on feed efficiency. High inclusion of $\mathrm{SBM}(>15 \%)$ is not related to higher FPCM but does increase the GWP of the TMR. In contrast, it is important to consider that high inclusion of roughages in the diet results in high enteric methane production that increases the GWP of the diets. The variability in the TMR GWP obtained in this study suggests that is possible to reduce the GWP of diets and, consequently, of milk production, through correct choice of ingredients and their dietary proportion while respecting dairy cow nutrient requirements. This suggestion could be useful for formulation of diets for heifers and calves, considering their important contribution to GHG emissions. In the future, when formulating a balanced diet, it will be important to include a GWP evaluation of both the feed and of the entire TMR to contribute to the overall sustainability of livestock production.

\section{ACKNOWLEDGMENTS}

The study was part of the project Forage4Climate (LIFE15 CCM/IT/000039) supported by EU commission. The authors have not stated any conflicts of interest.

\section{REFERENCES}

AgriFootprint. 2014. Agricultural footprint database. Blonk Consultants, Gouda, the Netherlands. Accessed Jul. 10, 2019. http:// www.agri-footprint.com.

Aguerre, M. J., M. A. Wattiaux, J. M. Powell, G. A. Broderick, and C. Arndt. 2011. Effect of forage-to-concentrate ratio in dairy cow diets on emission of methane, carbon dioxide, and ammonia, lactation performance, and manure excretion. J. Dairy Sci. 94:30813093. https://doi.org/10.3168/jds.2010-4011.

Appuhamy, J. A., J. France, and E. Kebreab. 2016. Models for predicting enteric methane emissions from dairy cows in North America, Europe, and Australia and New Zealand. Glob. Chang. Biol. 22:3039-3056. https://doi.org/10.1111/gcb.13339.

Arima, E. Y., P. Richards, R. Walker, and M. M. Caldas. 2011. Statistical confirmation of indirect land use change in the Brazilian Amazon. Environ. Res. Lett. 6:024010. https://doi.org/10.1088/ 1748-9326/6/2/024010.
Arriaga, H., M. Pinto, S. Calsamiglia, and P. Merino. 2009. Nutritional and management strategies on nitrogen and phosphorus use efficiency of lactating dairy cattle on commercial farms: An environmental perspective. J. Dairy Sci. 92:204-215. https://doi.org/ 10.3168/jds.2008-1304.

ASSALZOO (Associazione Nazionale tra i Produttori di Alimenti Zootecnici). 2018. Accessed Jun. 24, 2019. https://www.assalzoo.it/ pubblicazioni/annuario/.

Barona, E., N. Ramankutty, G. Hyman, and O. T. Coomes. 2010 The role of pasture and soybean in deforestation of the Brazilian Amazon. Environ. Res. Lett. 5:024002. https://doi.org/10.1088/ 1748-9326/5/2/024002.

Bava, L., A. Sandrucci, M. Zucali, M. Guerci, and A. Tamburini. 2014 How can farming intensification affect the environmental impact of milk production? J. Dairy Sci. 97:4579-4593. https://doi.org/10 $.3168 /$ jds.2013-7530.

Beauchemin, K. A., M. Kreuzer, F. O'Mara, and T. A. McAllister. 2008. Nutritional management for enteric methane abatement: A review. Aust. J. Exp. Agric. 48:21-27. https://doi.org/10.1071/ EA07199.

Benchaar, C., F. Hassanat, R. Gervais, P. Y. Chouinard, H. V. Petit, and D. I. Massé. 2014. Methane production, digestion, ruminal fermentation, nitrogen balance, and milk production of cows fed corn silage-or barley silage-based diets. J. Dairy Sci. 97:961-974. https://doi.org/10.3168/jds.2013-7122.

Boadi, D., C. Benchaar, J. Chiquette, and D. Massé. 2004. Mitigation strategies to reduce enteric methane emissions from dairy cows: Update review. Can. J. Anim. Sci. 84:319-335. https://doi.org/10 .4141/A03-109.

Brito, A. F., and G. A. Broderick. 2006. Effect of varying dietary ratios of alfalfa silage to corn silage on production and nitrogen utilization in lactating dairy cows. J. Dairy Sci. 89:3924-3938. https: //doi.org/10.3168/jds.S0022-0302(06)72435-3.

Clark, J. H., R. A. Frobish, K. E. Harshbarger, and R. G. Derrig. 1973. Feeding value of dry corn, ensiled high moisture corn, and propionic acid treated high moisture corn fed with hay or haylage for lactating dairy cows. J. Dairy Sci. 56:1531-1539. https://doi .org/10.3168/jds.S0022-0302(73)85403-7.

Clark, J. H., and K. E. Harshbarger. 1972. High-moisture corn versus dry corn in combination with either corn silage or hay for lactating cows. J. Dairy Sci. 55:1474-1480. https://doi.org/10.3168/jds .S0022-0302(72)85697-2.

Colombini, S., M. Zucali, L. Rapetti, G. M. Crovetto, A. Sandrucci, and L. Bava. 2015. Substitution of corn silage with sorghum silages in lactating cow diets: In vivo methane emission and global warming potential of milk production. Agric. Syst. 136:106-113. https:/ /doi.org/10.1016/j.agsy.2015.02.006.

De Brabander, D. L., B. G. Cottyn, and C. V. Boucqué. 1992. Substitution of concentrates by ensiled high-moisture maize grain in dairy cattle diets. Anim. Feed Sci. Technol. 38:57-67. https://doi .org/10.1016/0377-8401(92)90076-I.

Dhiman, T. R., and L. D. Satter. 1997. Yield response of dairy cows fed different proportions of alfalfa silage and corn silage. J. Dairy Sci. 80:2069-2082. https://doi.org/10.3168/jds.S0022-0302(97)76152 $-6$.

ECO-ALIM. 2015. Database ECO-ALIM. Accessed Jun. 15, 2019 https://www6.inra.fr/ecoalim_eng/Database-ECO-ALIM.

Ecoinvent. 2013. Ecoinvent database v. 3. Swiss Centre for Life Cycle Inventories, Zurich, Switzerland. Accessed Jun. 12, 2019. https:// www.ecoinvent.org/.

Ekinci, C., and G. A. Broderick. 1997. Effect of processing high moisture ear corn on ruminal fermentation and milk yield. J. Dairy Sci. 80:3298-3307. https://doi.org/10.3168/jds.S0022-0302(97)76305 -7 .

Evans, B. 2018. The role ensiled forage has on methane production in the rumen. Anim. Husb. Dairy Vet. Sci. 2:1-4.

FAO. 2019. Climate change and the global dairy cattle sector. Food and Agriculture Organization, Rome, Italy.

Ferraretto, L. F., P. M. Crump, and R. D. Shaver. 2013. Effect of cereal grain type and corn grain harvesting and processing methods on intake, digestion and milk production by dairy cows through a 
meta-analysis. J. Dairy Sci. 96:533-550. https://doi.org/10.3168/ jds.2012-5932.

Gallo, A., M. Moschini, C. Cerioli, and F. Masoero. 2013. Use of principal component analysis to classify forages and predict their calculated energy content. Animal 7:930-939. https://doi.org/10 $.1017 /$ S1751731112002467.

Gerber, P. J., H. Steinfeld, B. Henderson, A. Mottet, C. Opio, J. Dijkman, A. Falcucci, and G. Tempio. 2013. Tackling climate change through livestock-A global assessment of emissions and mitigation opportunities. Food and Agriculture Organization of the United Nations (FAO), Rome, Italy.

Giger-Reverdin, S., P. Morand-Fehr, and G. Tran. 2003. Literature survey of the influence of dietary fat composition on methane production in dairy cattle. Livest. Prod. Sci. 82:73-79. https://doi .org/10.1016/S0301-6226(03)00002-2.

Hassanat, F., R. Gervais, and C. Benchaar. 2017. Methane production, ruminal fermentation characteristics, nutrient digestibility, nitrogen excretion, and milk production of dairy cows fed conventional or brown midrib corn silage. J. Dairy Sci. 100:2625-2636. https:// doi.org/10.3168/jds.2016-11862.

Hassanat, F., R. Gervais, C. Julien, D. I. Massé, A. Lettat, P. Y. Chouinard, H. V. Petit, and C. Benchaar. 2013. Replacing alfalfa silage with corn silage in dairy cow diets: Effects on enteric methane production, ruminal fermentation, digestion, $\mathrm{N}$ balance, and milk production. J. Dairy Sci. 96:4553-4567. https://doi.org/10 $.3168 /$ jds.2012-6480.

Hegarty, R. S., and R. Gerdes. 1999. Hydrogen production and transfer in the rumen. Recent Adv. Anim. Nutr. Aust. 12:37-44.

Hopkins, A., and A. Del Prado. 2007. Implications of climate change for grassland in Europe: Impacts, adaptations and mitigation options: A review. Grass Forage Sci. 62:118-126. https://doi.org/10 $.1111 /$ j.1365-2494.2007.00575.x.

Hristov, A. N., J. Oh, J. L. Firkins, J. Dijkstra, E. Kebreab, G. Waghorn, H. P. S. Makkar, A. T. Adesogan, W. Yang, C. Lee, P. J. Gerber, B. Henderson, and J. M. Tricarico. 2013. Special topicsMitigation of methane and nitrous oxide emissions from animal operations: I. A review of enteric methane mitigation options. J. Anim. Sci. 91:5045-5069. https://doi.org/10.2527/jas.2013-6583.

IDF (International Dairy Federation). 2015. A common carbon footprint approach for dairy. The IDF guide to standard lifecycle assessment methodology for the dairy sector. Bulletin IDF No. 479/2010. IDF, Brussels, Belgium.

Jarecki, M. K., and R. Lal. 2003. Crop management for soil carbon sequestration. Crit. Rev. Plant Sci. 22:471-502. https://doi.org/10 $.1080 / 713608318$

Jenkins, T. C., and M. A. McGuire. 2006. Major advances in nutrition: Impact on milk composition. J. Dairy Sci. 89:1302-1310. https:// doi.org/10.3168/jds.S0022-0302(06)72198-1.

Johnson, D. E., G. W. Ward, and J. J. Ramsey. 1996. Livestock methane: Current emissions and mitigation potential. Pages 219-233 in Nutrient Management of Food Animals to Enhance and Protect the Environment. E. T. Kornegay, ed. Lewis Publishers, CRC Press Inc., Boca Raton, FL.

Johnson, K. A., and D. E. Johnson. 1995. Methane emissions from cattle. J. Anim. Sci. 73:2483-2492. https://doi.org/10.2527/1995 $.7382483 x$.

Knapp, J. R., G. L. Laur, P. A. Vadas, W. P. Weiss, and J. M. Tricarico. 2014. Invited review: Enteric methane in dairy cattle production: Quantifying the opportunities and impact of reducing emissions. J. Dairy Sci. 97:3231-3261. https://doi.org/10.3168/jds 2013-7234.

Lapola, D. M., R. Schaldach, J. Alcamo, A. Bondeau, J. Koch, C. Koelking, and J. A. Priess. 2010. Indirect land-use changes can overcome carbon savings from biofuels in Brazil. Proc. Natl. Acad. Sci. USA 107:3388-3393. https://doi.org/10.1073/pnas.0907318107.

Little, S., C. Benchaar, H. Janzen, R. Kröbel, E. McGeough, and K. Beauchemin. 2017. Demonstrating the effect of forage source on the carbon footprint of a Canadian dairy farm using whole-systems analysis and the Holos model: Alfalfa silage vs. corn silage. Climate (Basel) 5:87. https://doi.org/10.3390/cli5040087.
Martin, C., D. P. Morgavi, and M. Doreau. 2010. Methane mitigation in ruminants: From microbe to the farm scale. Animal 4:351-365. https://doi.org/10.1017/S1751731109990620.

McCaffree, J. D., and W. G. Merrill. 1968. High moisture corn for dairy cows in early lactation. J. Dairy Sci. 51:553-560. https://doi .org/10.3168/jds.S0022-0302(68)87028-6.

Olmos Colmenero, J. F., and G. A. Broderick. 2006. Effect of dietary crude protein concentration on milk production and nitrogen utilization in lactating dairy cows. J. Dairy Sci. 89:1704-1712. https:/ /doi.org/10.3168/jds.S0022-0302(06)72238-X.

O'Mara, F. P., J. J. Fitzgerald, J. J. Murphy, and M. Rath. 1998. The effect on milk production of replacing grass silage with maize silage in the diet of dairy cows. Livest. Prod. Sci. 55:79-87. https: //doi.org/10.1016/S0301-6226(98)00115-8.

Ogino, A., H. Orito, K. Shimada, and H. Hirooka. 2007. Evaluating environmental impacts of the Japanese beef cow-calf system by the life cycle assessment method. Anim. Sci. J. 78:424-432. https: //doi.org/10.1111/j.1740-0929.2007.00457.x.

Phuong, H. N., N. C. Friggens, I. J. M. de Boer, and P. Schmidely. 2013. Factors affecting energy and nitrogen efficiency of dairy cows: A meta-analysis. J. Dairy Sci. 96:7245-7259. https://doi .org/10.3168/jds.2013-6977.

Pirondini, M., S. Colombini, M. Mele, L. Malagutti, L. Rapetti, G. Galassi, and G. M. Crovetto. 2015. Effect of dietary starch concentration and fish oil supplementation on milk yield and composition, diet digestibility, and methane emissions in lactating dairy cows. J. Dairy Sci. 98:357-372. https://doi.org/10.3168/jds.2014 -8092 .

Pirondini, M., L. Malagutti, S. Colombini, P. Amodeo, and G. M. Crovetto. 2012. Methane yield from dry and lactating cows diets in the Po Plain (Italy) using an in vitro gas production technique. Ital. J. Anim. Sci. 11:e61. https://doi.org/10.4081/ijas.2012.e61.

Powell, J. M., C. A. Rotz, P. A. Vadas, and K. F. Reed. 2016. Substitutions of corn silage, alfalfa silage and corn grain in cow rations impact N use and N loss from dairy farms. Proc. 2016 Int. Nitrogen Initiative Conf. Solutions to Improve Nitrogen Use Efficiency for the World, Melbourne, Australia. Accessed Feb. 12, 2020. http: //www.ini2016.com/pdf-papers/INI2016.

Tylutki, T. P., D. G. Fox, V. M. Durbal, L. O. Tedeschi, J. B. Russell, M. E. Van Amburgh, T. R. Overton, L. E. Chase, and A. N. Pell. 2008. Cornell Net Carbohydrate and Protein System: A model for precision feeding of dairy cattle. Anim. Feed Sci. Technol. 143:174202. https://doi.org/10.1016/j.anifeedsci.2007.05.010.

Van Amburgh, M. E., E. A. Collao-Saenz, R. J. Higgs, D. A. Ross, E. B. Recktenwald, E. Raffrenato, L. E. Chase, T. R. Overton, J. K. Mills, and A. Foskolos. 2015. The Cornell Net Carbohydrate and Protein System: Updates to the model and evaluation of version 6.5. J. Dairy Sci. 98:6361-6380. https://doi.org/10.3168/jds.2015 $-9378$.

van Gastelen, S., E. C. Antunes-Fernandes, K. A. Hettinga, G. Klop, S. J. J. Alferink, W. H. Hendriks, and J. Dijkstra. 2015. Enteric methane production, rumen volatile fatty acid concentrations, and milk fatty acid composition in lactating Holstein-Friesian cows fed grass silage-or corn silage-based diets. J. Dairy Sci. 98:1915-1927. https://doi.org/10.3168/jds.2014-8552.

Zucali, M., J. Bacenetti, A. Tamburini, L. Nonini, A. A. Sandrucci, and L. Bava. 2018. Environmental impact assessment of different cropping systems of home-grown feed for milk production. J. Clean. Prod. 172:3734-3746. https://doi.org/10.1016/j.jclepro .2017.07.048.

\section{ORCIDS}

G. Gislon ๑ https://orcid.org/0000-0003-0389-7960

L. Bava $\odot$ https://orcid.org/0000-0001-6521-3195

S. Colombini $\odot$ https://orcid.org/0000-0002-4391-3905

M. Zucali $\odot$ https://orcid.org/0000-0002-2380-3274

G. M. Crovetto (®) https://orcid.org/0000-0003-1156-2087

A. Sandrucci 1 https://orcid.org/0000-0002-1014-0088 